\title{
Inhella fonticola sp. nov., isolated from spring water, and emended description of the genus Inhella
}

Correspondence

Shih-Yi Sheu

sys816@mail.nkmu.edu.tw
Wen-Ming Chen, ${ }^{1}$ Fu-Sian Sheu, ${ }^{2}$ Chiu-Chung Young ${ }^{3}$ and Shih-Yi Sheu ${ }^{2}$

${ }^{1}$ Laboratory of Microbiology, Department of Seafood Science, National Kaohsiung Marine University, No. 142, Hai-Chuan Rd, Nan-Tzu, Kaohsiung City 811, Taiwan, ROC

${ }^{2}$ Department of Marine Biotechnology, National Kaohsiung Marine University, No. 142, Hai-Chuan Rd, Nan-Tzu, Kaohsiung City 811, Taiwan, ROC

${ }^{3}$ College of Agriculture and Natural Resources, Department of Soil and Environmental Sciences, National Chung Hsing University, Taichung 402, Taiwan, ROC

A yellow-pigmented bacterial strain designated TNR- $25^{\top}$ was isolated from spring water in Taiwan and was characterized using a polyphasic taxonomic approach. Strain TNR-25 ${ }^{\top}$ was Gram-negative, obligately aerobic, rod-shaped, non-motile and non-spore-forming. Growth occurred at $15-40{ }^{\circ} \mathrm{C}$ (optimum, $25^{\circ} \mathrm{C}$ ), at $\mathrm{pH} 6.0-10.0$ (optimum, $\mathrm{pH} 7.0$ ) and with 0-0.5\% $\mathrm{NaCl}$ (optimum, 0\%). Phylogenetic analyses based on 16S rRNA gene sequences showed that strain TNR- $25^{\top}$ belonged to the genus Inhella and its closest neighbour was Inhella inkyongensis IMCC $1713^{\top}$ with $98.1 \%$ sequence similarity. The major fatty acids (>10\%) of strain TNR-25 ${ }^{\top}$ were summed feature 3 (comprising $\mathrm{C}_{16: 1} \omega 7 c$ and/or $\mathrm{C}_{16: 1} \omega 6 c$ ) and $\mathrm{C}_{16: 0}$. The major cellular hydroxy fatty acids were $\mathrm{C}_{10: 0} 3-\mathrm{OH}$ and $\mathrm{C}_{12: 0} 3-\mathrm{OH}$. The isoprenoid quinone was $\mathrm{Q}-8$ and the DNA G + C content was 69.6 mol\%. The polar lipid profile consisted of a mixture of phosphatidylethanolamine, phosphatidylglycerol, phosphatidylserine, diphosphatidylglycerol and several uncharacterized phospholipids. The DNA-DNA relatedness between strain TNR- $25^{\top}$ and I. inkyongensis IMCC $1713^{\top}$ was about 30.6-35.5\%. On the basis of the genotypic and phenotypic data, strain TNR-25 ${ }^{\top}$ represents a novel species in the genus Inhella, for which the name Inhella fonticola sp. nov. is proposed; the type strain is TNR-25 ${ }^{\top}\left(=\mathrm{BCRC} 80211^{\top}=\mathrm{LMG}\right.$ $\left.25721^{\top}\right)$.
At the time of writing, the order Burkholderiales (Garrity et al., 2005) in the class Betaproteobacteria encompassed four families, Burkholderiaceae, Oxalobacteraceae, Alcaligenaceae and Comamonadaceae, that have been circumscribed largely based on 16S rRNA gene sequence-based phylogeny. Although there has been a well-defined taxonomic hierarchy among the members of the order Burkholderiales, the positions of several genera closely related to the family Comamonadaceae have been known to be taxonomically uncertain and these genera have been classified as incertae sedis (Willems \& Gillis, 2005). This phylogenetically uncertain group, called the SphaerotilusLeptothrix group (Spring, 2002), contains metabolically diverse genera such as Aquabacterium, Roseateles, Rubrivivax,

Abbreviations: DPG, diphosphatidylglycerol; PE, phosphatidylethanolamine; PG, phosphatidylglycerol; $\mathrm{PHB}$, poly- $\beta$-hydroxybutyrate; $\mathrm{PL}$, phospholipid; PS, phosphatidylserine.

The GenBank/EMBL/DDBJ accession number for the 16S rRNA gene sequence of Inhella fonticola TNR-25 ${ }^{\top}$ is HM013811.

A supplementary figure and a supplementary table are available with the online version of this paper.
Leptothrix, Sphaerotilus, Mitsuaria, Paucibacter, Methylibium and Aquincola.

The genus Inhella, which belongs to the SphaerotilusLeptothrix group within the order Burkholderiales, class Betaproteobacteria, was proposed by Song et al. (2009). At the time of writing, this genus comprised only one recognized species, Inhella inkyongensis, which was isolated from a highly eutrophic artificial pond (Song et al., 2009). Members of the genus Inhella are characterized as Gram-negative, flagellated, short to long rod-shaped, chemoheterotrophic, obligately aerobic, oxidase-positive and catalase-negative, and contain poly- $\beta$-hydroxybutyrate (PHB) granules. Chemotaxonomically, they have large amounts of summed feature 3 $\left(\mathrm{C}_{16: 1} \omega 7 c\right.$ and/or $\left.\mathrm{C}_{16: 1} \omega 6 c\right), \mathrm{C}_{16: 0}$ and $\mathrm{C}_{10: 0} 3-\mathrm{OH}$, and Q-8 and Q-6 as respiratory quinones (Song et al., 2009). The present study was carried out to clarify the taxonomic position of an Inhella-like bacterial strain $\left(\mathrm{TNR}-25^{\mathrm{T}}\right)$ by using a polyphasic taxonomy approach.

During the characterization of micro-organisms from a freshwater spring in the Maolin Township (GPS location: 
$22^{\circ} 54^{\prime} 12.5^{\prime \prime} \mathrm{N} \quad 120^{\circ} 40^{\prime} 59.9^{\prime \prime} \mathrm{E} ; \quad \mathrm{pH} 7.5, \quad 25^{\circ} \mathrm{C}$ ) in Kaoshiung County, Taiwan, a yellow-coloured strain TNR $-25^{\mathrm{T}}$ was isolated and selected for detailed analysis. Strain TNR-25 ${ }^{\mathrm{T}}$ was isolated on R2A agar (BD Difco) plates after incubation at $25{ }^{\circ} \mathrm{C}$ for 3 days. Subcultivation was performed on R2A agar at $25{ }^{\circ} \mathrm{C}$ for $48-72 \mathrm{~h}$. On this medium, strain TNR- $25^{\mathrm{T}}$ was able to grow at $15-40{ }^{\circ} \mathrm{C}$. It was preserved at $-80{ }^{\circ} \mathrm{C}$ in $\mathrm{R} 2 \mathrm{~A}$ broth with $20 \%(\mathrm{v} / \mathrm{v})$ glycerol or by lyophilization. I. inkyongensis strains NBRC $103252^{\mathrm{T}}$ and CCUG $54308^{\mathrm{T}}$ were obtained from the NITE Biological Research Center (NBRC) and the Culture Collection, University of Göteborg (CCUG), respectively. These two type strains were used as reference strains for phenotypic and genotypic tests.

Bacterial cells were observed by phase-contrast microscopy (DM 2000; Leica) using cells grown on R2A agar at $25{ }^{\circ} \mathrm{C}$ for $6 \mathrm{~h}$ (lag growth phase), $18 \mathrm{~h}$ (exponential phase) and $36 \mathrm{~h}$ (stationary phase) to ascertain the morphology. Motility was tested by the hanging-drop method (Murray et al., 1994). The Gram Stain Set S (BD Difco) kit and the Ryu nonstaining KOH method (Powers, 1995) were used for testing the Gram reaction. PHB granule accumulation was observed under light microscopy after staining of the cells with Sudan black. Colony morphology was observed on R2A agar using a stereoscopic microscope (SMZ 800; Nikon).

The $\mathrm{pH}$ range for growth was determined by measuring the $\mathrm{OD}_{600}$ of $\mathrm{R} 2 \mathrm{~A}$ broth cultures. The $\mathrm{pH}$ was adjusted prior to sterilization to $\mathrm{pH} 4-10$ (at intervals of $1.0 \mathrm{pH}$ unit) using appropriate biological buffers (Breznak \& Costilow, 1994): citrate $/ \mathrm{Na}_{2} \mathrm{HPO}_{4}$ buffer, $\mathrm{pH}$ range 4.0-5.0; phosphate buffer, $\mathrm{pH}$ range 6.0-7.0; Tris buffer, $\mathrm{pH}$ range 8.0-9.0; no buffer, $\mathrm{pH}$ 10.0. Verification of the $\mathrm{pH}$ values after autoclaving revealed only minor changes. The temperature range for growth was determined on R2A agar at $4-50{ }^{\circ} \mathrm{C}$. To investigate $\mathrm{NaCl}$ tolerance, $\mathrm{R} 2 \mathrm{~A}$ broth was prepared according to the formula of the BD Difco medium with the $\mathrm{NaCl}$ concentration adjusted to $0 \%, 0.5 \%$ and $1.0-6.0 \%$, $\mathrm{w} / \mathrm{v}$ (at intervals of $1.0 \%$ ). Growth under anaerobic conditions was determined after incubating the bacterial strains on R2A agar in the Oxoid AnaeroGen system. Bacterial strains were examined for a broad range of phenotypic properties. Activities of catalase, oxidase, DNase, urease and lipase (corn oil), and hydrolysis of starch, casein, gelatin, lecithin, and Tweens 20, 40, 60 and 80 were determined using standard methods (Smibert \& Krieg, 1994). Additional, biochemical tests were performed using API ZYM, and API 20NE kits (bioMérieux) and carbon source utilization was evaluated using GN2 MicroPlates (Biolog). All commercial phenotypic tests were performed according to the manufacturers' recommendations.

For photosynthetic pigment analysis, bacterial strains were cultivated aerobically in the dark for 2 days at $25^{\circ} \mathrm{C}$ in broth culture; Roseivivax halodurans JCM $10272^{\mathrm{T}}$ and Roseivivax halotolerans JCM $10271^{\mathrm{T}}$ were used as positive controls. The cell mass from $30 \mathrm{ml}$ culture was extracted with $3 \mathrm{ml}$ acetone/methanol $(7: 2, \mathrm{v} / \mathrm{v})$ and the absorption spectrum of the extract was recorded (Biebl et al., 2005). The absorption spectrum of the pigments was examined on a Thermo Helios $\gamma$ spectrophotometer. The presence of bacteriochlorophyll $a$ in bacterial strains is typically indicated by maxima of 367 and $775 \mathrm{~nm}$ in the absorption spectrum.

Sensitivity of bacterial strains to antibiotics was tested by the disc-diffusion method after spreading cell suspensions (0.5 McFarland) on R2A agar (BD Difco) plates. Discs (Oxoid) contained the following antibiotics $(\mu \mathrm{g})$ : ampicillin (10), chloramphenicol (30), gentamicin (10), kanamycin (30), nalidixic acid (30), novobiocin (30), rifampicin (5), penicillin G (10), streptomycin (10), sulfamethoxazole (23.75) plus trimethoprim (1.25), tetracycline (30), vancomycin (30) and erythromycin (15). The effect of antibiotics on cell growth was assessed after 2 days at $25^{\circ} \mathrm{C}$. The diameter of antibiotic disc was $8 \mathrm{~mm}$ and the strain was considered susceptible when the diameter of the inhibition zone was $>13 \mathrm{~mm}$, intermediate at $10-12 \mathrm{~mm}$ and resistant at $<10 \mathrm{~mm}$ as described by Nokhal \& Schlegel (1983).

Genomic DNA was isolated by a bacterial genomic DNA purification kit (DP02-150, GeneMark Technology) and the 16S rRNA gene sequence was analysed as described previously by Chen et al. (2001). Primers FD1 (5'-AGAGTTTGATCCTGGCTCAG-3') and RD1 (5'-AAGGAGGTGATCCAGCC-3') were used for amplification of bacterial 16S rRNA genes by PCR. These primers correspond to nucleotide positions 8-27 and 1525-1541 of the Escherichia coli 16S rRNA gene, respectively, and can be used for amplifying the nearly full-length $16 \mathrm{~S}$ rRNA gene. The PCR product was purified and direct sequencing was performed by using sequencing primers FD1, RD1, 520F and $800 \mathrm{R}$ (Weisburg et al., 1991; Anzai et al., 1997) with a DNA sequencer (ABI Prism 3730; Applied Biosystems). An almost-complete $16 \mathrm{~S}$ rRNA gene sequence (1451 nt) of strain TNR- $25^{\mathrm{T}}$ was compared against $16 \mathrm{~S}$ rRNA gene sequences available from the EzTaxon server (Chun et al., 2007), the Ribosomal Database Project (Maidak et al., 2001) and GenBank (http://blast.ncbi.nlm.nih.gov/Blast.cgi). Analysis of the sequence data was performed by using the software package BioEdit (Hall, 1999) and MEGA version 3.1 (Kumar et al., 2004), after multiple alignments of the data by CLUSTAL_X (Thompson et al., 1997). The resulting multiple sequence alignment was corrected manually and gaps at the $5^{\prime}$ and $3^{\prime}$ ends of the alignment were omitted for further analyses. Distances (corrected according to Kimura's twoparameter model; Kimura, 1983) were calculated and clustering was performed with the neighbour-joining method (Saitou \& Nei, 1987). The maximum-likelihood (Felsenstein, 1981) and maximum-parsimony (Kluge \& Farris, 1969) trees were generated by using the treeing algorithms contained in the PHYLIP software package (Felsenstein, 1993). In each case, bootstrap values were calculated based on 1000 replications.

$16 \mathrm{~S}$ rRNA gene sequence analysis indicated that strain TNR- $25^{\mathrm{T}}$ belonged to the Sphaerotilus-Leptothrix group of the order Burkholderiales in the class Betaproteobacteria. 
Strain TNR- $25^{\mathrm{T}}$ formed a distinct subline within the genus Inhella in the neighbour-joining tree (Fig. 1). The overall topologies of the phylogenetic trees obtained with the maximum-likelihood and maximum-parsimony methods were similar. Sequence similarity calculations (over $1400 \mathrm{bp}$ ) indicated that strain TNR- $25^{\mathrm{T}}$ was closely related to I. inkyongensis $\mathrm{IMCC}_{1713^{\mathrm{T}}}(98.1 \% 16 \mathrm{~S}$ rRNA gene sequence similarity). Lower sequence similarities $(<96.5 \%)$ were found with representative members of all other genera listed in Fig. 1.

DNA-DNA hybridization experiments were carried out by the method of Ezaki et al. (1989). The level of DNA-DNA relatedness of strain TNR $-25^{\mathrm{T}}$ with $I$. inkyongensis NBRC $103252^{\mathrm{T}}$ was $30.6 \pm 2.5 \%(33.4 \pm 4.2 \%$ in a reciprocal experiment). The level of DNA-DNA relatedness of strain TNR- $25^{\mathrm{T}}$ with $I$. inkyongensis CCUG $54308^{\mathrm{T}}$ was $35.5 \pm$ $1.8 \%(32.6 \pm 2.3 \%$ in a reciprocal experiment). Since the recommended DNA-DNA relatedness threshold for the definition of a species is $70 \%$ (Wayne et al., 1987), these results indicate that strain TNR- $25^{\mathrm{T}}$ does not belong to the known species of the genus Inhella.

The fatty acid profiles of strain TNR-25 $5^{\mathrm{T}}$, I. inkyongensis NBRC $103252^{\mathrm{T}}$ and I. inkyongensis CCUG $54308^{\mathrm{T}}$ were determined using cells grown on R2A agar at $25{ }^{\circ} \mathrm{C}$ for 2 days. The fatty acid methyl esters were prepared and separated according to the instructions of the Microbial Identification System (MIDI; Sasser, 1990) and identified by MIDI version 6.0 and the RTSBA6.00 database. The fatty acid profile of strain TNR- $25^{\mathrm{T}}$ was similar to those of strains of $I$. inkyongensis, although there were differences in the proportions of some components (Table 1). The major fatty acids $(>10 \%)$ of strain TNR- $25^{\mathrm{T}}$ and $I$. inkyongensis were summed feature 3 (comprising $\mathrm{C}_{16: 1} \omega 7 c$ and/or $\mathrm{C}_{16: 1} \omega 6 c$ ) and $\mathrm{C}_{16: 0}$. The major cellular hydroxy fatty acids in strain TNR- $25^{\mathrm{T}}$ were $\mathrm{C}_{10: 0} 3-\mathrm{OH}$ and $\mathrm{C}_{12: 0} 3-\mathrm{OH}$. Furthermore, the quantity of fatty acid $\mathrm{C}_{18: 1} \omega 7 \mathrm{c}$ in strain TNR $-25^{\mathrm{T}}$ was higher than that of I. inkyongensis. In contrast to results reported previously (Song et al., 2009), I. inkyongensis strains NBRC $103252^{\mathrm{T}}$ and CCUG $54308^{\mathrm{T}}$ contained the fatty acids $\mathrm{C}_{18: 0}$, anteiso- $\mathrm{C}_{11: 0}$, anteiso- $\mathrm{C}_{12: 0}$ and $\mathrm{C}_{16: 1} \omega 7 \mathrm{c}$ alcohol as minor components.

Isoprenoid quinones were extracted and purified according to the method of Collins (1985) and were analysed by HPLC. The respiratory quinones of strain TNR- $25^{\mathrm{T}}$ detected were Q-8 (92.9\%) and Q-6 (7.1\%), whereas the respiratory quinones of I. inkyongensis NBRC $103252^{\mathrm{T}}$ detected were Q$8(88 \%)$ and Q-6 (12\%). The respiratory quinones of strain TNR- $25^{\mathrm{T}}$ were similar to those reported previously for $I$. inkyongensis (Song et al., 2009), although there were differences in the proportions.

The DNA G + C content of strain TNR $-25^{\mathrm{T}}$, determined by HPLC according to Mesbah et al. (1989), was $69.6 \pm$ $1.0 \mathrm{~mol} \%$. The DNA G+C contents of I. inkyongensis strains NBRC $103252^{\mathrm{T}}$ and CCUG $54308^{\mathrm{T}}$ were $70.1 \pm 1.0$ and $68.7 \pm 1.0 \mathrm{~mol} \%$, which are much higher than those reported previously (Song et al., 2009). However, this result

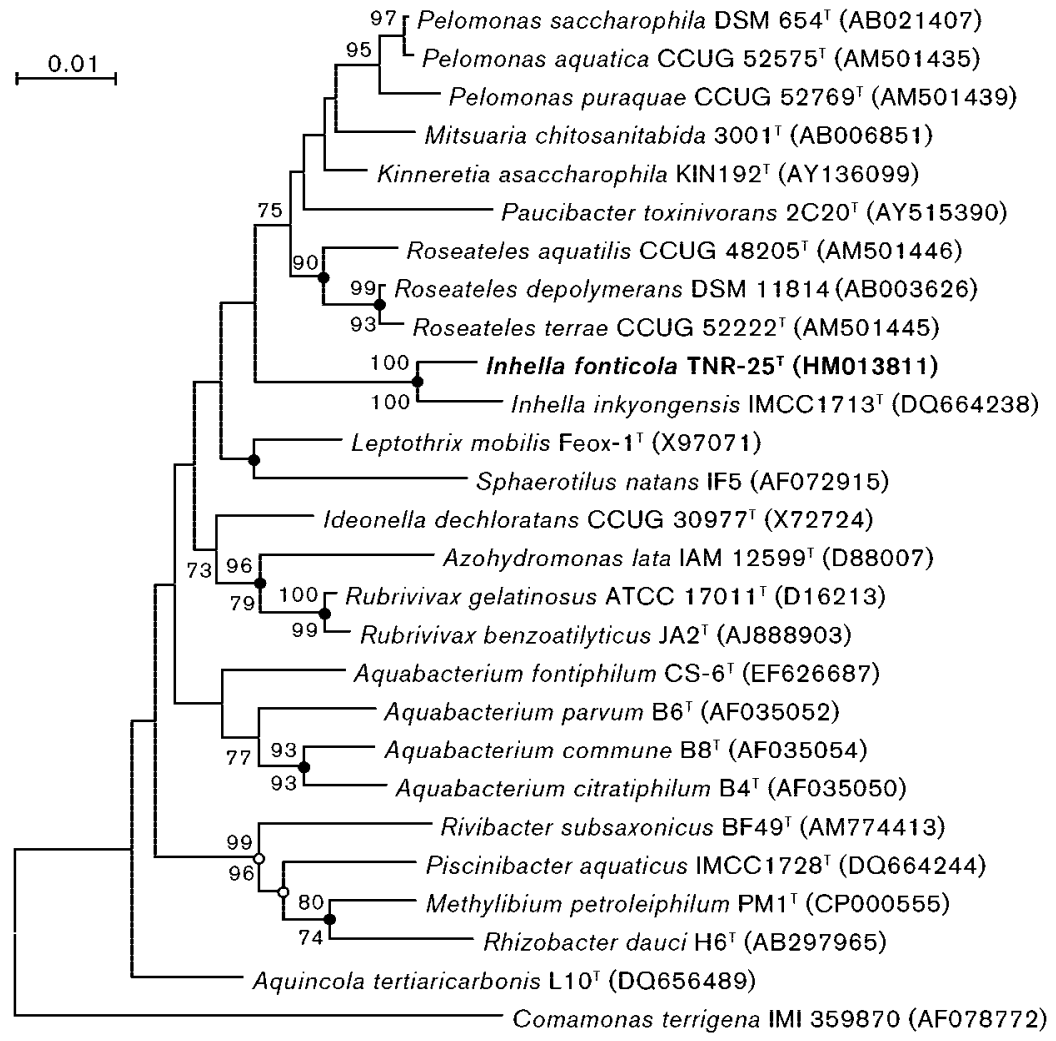

Fig. 1. Neighbour-joining phylogenetic tree based on 16S rRNA gene sequences showing the position of Inhella fonticola TNR- $25^{\top}$ and related taxa in the order Burkholderiales of the class Betaproteobacteria. Numbers at nodes are bootstrap percentages $>70 \%$ based on the neighbour-joining (above nodes) and maximum-parsimony (below nodes) tree-making algorithms. Filled circles indicate branches of the tree that were also recovered using the maximum-likelihood and maximum-parsimony tree-making algorithms. Open circles indicate that the corresponding nodes were also recovered in the tree generated with the maximumparsimony algorithm. Comamonas terrigena IMI 359870 was used as an outgroup. Bar, 0.01 substitutions per nucleotide position. 
Table 1. Cellular fatty acid composition of Inhella species

Taxa: 1, Inhella fonticola TNR-25 ${ }^{\mathrm{T}} ; 2$, Inhella inkyongensis (data for strains NBRC $103252^{\mathrm{T}}$ and CCUG $54308^{\mathrm{T}}$ ). For unsaturated fatty acids, the position of the double bond is located by counting from the methyl $(\omega)$ end of the carbon chain; the cis isomer is indicated by the suffix $c$. All data are from this study. Bacterial strains were grown on $\mathrm{R} 2 \mathrm{~A}$ agar at $25{ }^{\circ} \mathrm{C}$ for 2 days. Values are percentages of the total fatty acids; fatty acids that make up $<0.6 \%$ of the total are not shown or indicated by '-'.

\begin{tabular}{|c|c|c|}
\hline Fatty acid & 1 & 2 \\
\hline $\mathrm{C}_{12: 0}$ & 3.3 & $2.9-3.1$ \\
\hline $\mathrm{C}_{14: 0}$ & 0.6 & $1.0-2.2$ \\
\hline$C_{16: 0}$ & 23.7 & $25.5-29.1$ \\
\hline $\mathrm{C}_{17: 0}$ & 1.0 & $0.7-1.1$ \\
\hline $\mathrm{C}_{18: 0}$ & 2.9 & $3.5-4.4$ \\
\hline $\mathrm{C}_{10: 0} 3-\mathrm{OH}$ & 5.4 & $6.6-7.4$ \\
\hline $\mathrm{C}_{12: 0} 3-\mathrm{OH}$ & 2.5 & $1.2-2.1$ \\
\hline anteiso- $\mathrm{C}_{11: 0}$ & 1.4 & $1.3-2.0$ \\
\hline anteiso- $\mathrm{C}_{12: 0}$ & 1.1 & $1.2-1.6$ \\
\hline iso- $\mathrm{C}_{16: 0}$ & - & $0.8-1.1$ \\
\hline $\mathrm{C}_{15: 1} \omega 6 c$ & - & $0.7-0.9$ \\
\hline $\mathrm{C}_{16: 1} \omega 7 c$ alcohol & 1.1 & $0.6-0.9$ \\
\hline $\mathrm{C}_{18: 1} \omega 7 c$ & 7.1 & $0.9-1.7$ \\
\hline $\mathrm{C}_{18: 1} \omega 9 c$ & 1.4 & $0.6-1.0$ \\
\hline Summed feature $3^{\star}$ & 45.2 & $39.1-43.5$ \\
\hline
\end{tabular}

* Summed features are groups of two or three fatty acids that cannot be separated by GLC using the MIDI system. Summed feature 3 comprises $\mathrm{C}_{16: 1} \omega 7 c$ and/or $\mathrm{C}_{16: 1} \omega 6 c$.

is close to those of other members of the SphaerotilusLeptothrix group: Sphaerotilus, $69 \mathrm{~mol} \%$ (Spring, 2002; Willems \& Gillis, 2005); Leptothrix, 68-71 mol\% (Spring et al., 1996; Willems \& Gillis, 2005); Roseateles, 66 mol\% (Suyama et al., 1999; Gomila et al., 2008); Rubrivivax, 70$74 \mathrm{~mol} \%$ (Willems et al., 1991; Ramana et al., 2006); Paucibacter, $67 \mathrm{~mol} \%$ (Rapala et al., 2005); Ideonella, $68 \mathrm{~mol} \%$ (Malmqvist et al., 1994); Aquabacterium, 6566 mol\% (Kalmbach et al., 1999).

Polar lipids were extracted and analysed by two-dimensional TLC according to Embley \& Wait (1994). Molybdophosphoric acid was used for detection of all lipids, ninhydrin reagent was used for lipids containing free amino groups, Zinzadze reagent was used for phosphoruscontaining lipids and $\alpha$-naphthol reagent was used for glycolipids. Strain TNR- $25^{\mathrm{T}}$ exhibited a complex polar lipid profile consisting of phosphatidylethanolamine (PE), phosphatidylglycerol (PG), phosphatidylserine (PS), diphosphatidylglycerol (DPG) and several uncharacterized phospholipids (PL1-PL4) (see Fig. S1 available in IJSEM Online). Like its closest relative I. inkyongensis NBRC $103252^{\mathrm{T}}$, strain TNR-25 $5^{\mathrm{T}}$ exhibited a very similar polar lipid profile, with both strains possessing PE, PG, PS, DPG and PL2-PL4. However, an uncharacterized phospholipid (PL1) was present in strain TNR-25 ${ }^{\mathrm{T}}$, but absent in $I$. inkyongensis $\mathrm{NBRC} 103252^{\mathrm{T}}$. This result suggest that there are some differences in the polar lipid profiles between both strains, although they belong to the same genus and have very similar profiles.

The physiological, biochemical and morphological characteristics of strain $\mathrm{TNR}-25^{\mathrm{T}}$ are given in the species description, Table 2 and Table S1 (available in IJSEM Online). Phenotypic examination revealed many common traits between the novel strain and its closest relatives, $I$. inkyongensis strains NBRC $103252^{\mathrm{T}}$ and CCUG $54308^{\mathrm{T}}$. However, strain TNR- $25^{\mathrm{T}}$ could be clearly differentiated from these two strains based on the following characteristics: colony pigmentation; cell motility; ability to hydrolyse starch and lecithin; ability to assimilate caprate; inability to grow at higher $\mathrm{NaCl}$ concentrations, at higher temperatures and under anaerobic conditions; inability to reduce nitrate; the absence of $\beta$-galactosidase and $\alpha$-chymotrypsin activities; the inability to assimilate glucose, arabinose, mannose, mannitol, maltose and malate; and sensitivity to penicillin G, ampicillin, rifampicin and sulfamethoxazole/trimethoprim (Table 2). In addition, strain TNR $-25^{\mathrm{T}}$ could be also distinguished from I. inkyongensis NBRC $103252^{\mathrm{T}}$ by its ability to utilize $\alpha$-cyclodextrin, dextrin, glycogen, adonitol, sucrose, $\beta$-hydroxybutyric acid, sebacic acid, L-asparagine, L-histidine, L-ornithine, uridine and 2-aminoethanol as sole carbon sources (Table S1).

Strain TNR- $25^{\mathrm{T}}$ is Gram-negative, rod-shaped, chemoheterotrophic and oxidase-positive, and contains PHB granules. It has a large amount of summed feature 3 (comprising $\mathrm{C}_{16: 1} \omega 7 c$ and/or $\left.\mathrm{C}_{16: 1} \omega 6 c\right)$ and $\mathrm{C}_{16: 0}$. Its major cellular hydroxy fatty acids are $\mathrm{C}_{10: 0} 3-\mathrm{OH}$ and $\mathrm{C}_{12: 0} 3-\mathrm{OH}$, and it has the respiratory quinones Q-8 and Q-6. These characteristics of strain TNR $-25^{\mathrm{T}}$ are consistent with the description of the genus Inhella (Song et al., 2009). On the basis of the data obtained from 16S rRNA gene sequence comparisons, strain TNR-2 $25^{\mathrm{T}}$ occupies a distinct position within the genus Inhella; this is supported by the unique combination of chemotaxonomic and biochemical characteristics of the isolate. It is clear from phylogenetic and phenotypic data that strain TNR $-25^{\mathrm{T}}$ constitutes a novel member of the genus Inhella. However, strain TNR $-25^{\mathrm{T}}$ could be differentiated from I. inkyongensis strains NBRC $103252^{\mathrm{T}}$ and CCUG $54308^{\mathrm{T}}$ by a combination of physiological and biochemical characteristics (Table 2 and Table S1). Hence, strain $\mathrm{TNR}-25^{\mathrm{T}}$ represents a second species of the genus Inhella for which the name Inhella fonticola sp. nov. is proposed.

The abilities to grow under anaerobic conditions and reduce nitrate were not observed previously for I. inkyongensis by Song et al. (2009), who reported that I. inkyongensis was weakly positive for nitrate reduction and unable to grow under anaerobic conditions. Additionally, the DNA G + C contents of Inhella species differed from those reported previously (Song et al., 2009). Hence, an emended description of the genus Inhella is proposed. 
Table 2. Differential characteristics of Inhella species

Taxa: 1, Inhella fonticola TNR-25 $5^{\mathrm{T}}$; 2 , Inhella inkyongensis (data for strains NBRC $103252^{\mathrm{T}}$ and CCUG $54308^{\mathrm{T}}$ ). All data are from this study except where marked. +, Positive; -, negative reaction; $\mathrm{w}$, weakly positive; v, variable. All three strains are Gram-negative, rodshaped, mesophilic, neutrophilic and non-spore-forming, contain PHB granules, lack bacteriochlorophyll $a$ and are positive for oxidase, DNase, alkaline phosphatase, C4 esterase, C8 esterase lipase, leucine arylamidase, acid phosphatase, naphthol-AS-BI-phosphohydrolase activities, and positive for hydrolysis of Tweens 40 and 80. All three strains are negative for urease, arginine dihydrolase, C14 lipase, valine arylamidase, cystine arylamidase, trypsin, $\alpha$-galactosidase, $\beta$-glucuronidase, $\alpha$-glucosidase, $\beta$-glucosidase, $N$-acetyl- $\beta$-glucosaminidase, $\alpha$ mannosidase and $\alpha$-fucosidase activities, indole production, glucose acidification, assimilation of $\mathrm{N}$-acetylglucosamine, gluconate, adipate, citrate and phenylacetate, and hydrolysis of casein, corn oil, gelatin and Tweens 20 and 60. All three strains are sensitive to chloramphenicol, gentamicin, kanamycin, tetracycline, novobiocin, streptomycin, nalidixic acid, vancomycin and erythromycin.

\begin{tabular}{|c|c|c|}
\hline Characteristic & 1 & 2 \\
\hline Colony pigmentation & Yellow & White \\
\hline Motility & - & + \\
\hline $\begin{array}{l}\mathrm{NaCl} \text { range for growth } \\
(\%)\end{array}$ & $0-0.5$ & $0-1.0(0-0.7)^{\star}$ \\
\hline $\begin{array}{l}\text { Temperature for } \\
\text { optimal growth }\left({ }^{\circ} \mathrm{C}\right)\end{array}$ & 25 & $30(25)^{\star}$ \\
\hline Growth at $37{ }^{\circ} \mathrm{C}$ & + & $+(-)^{*}$ \\
\hline Nitrate reduction & - & $+(\mathrm{w})^{*}$ \\
\hline \multicolumn{3}{|l|}{ Hydrolysis of: } \\
\hline Starch & + & - \\
\hline Lecithin & + & - \\
\hline Aesculin & - & $-(w)^{*}$ \\
\hline Gelatin & - & $-(w)^{*}$ \\
\hline \multicolumn{3}{|l|}{ Enzymic activities } \\
\hline Catalase & + & - \\
\hline$\beta$-Galactosidase & - & $\mathrm{v} \dagger$ \\
\hline$\alpha$-Chymotrypsin & - & + \\
\hline Leucine arylamidase & + & $+(-)^{*}$ \\
\hline \multicolumn{3}{|l|}{ Assimilation of: } \\
\hline Glucose & - & + \\
\hline Arabinose & - & + \\
\hline Mannose & - & + \\
\hline Mannitol & - & + \\
\hline Maltose & - & + \\
\hline Caprate & + & - \\
\hline Malate & - & + \\
\hline \multicolumn{3}{|l|}{ Susceptibility to: $\ddagger$} \\
\hline Penicillin G & S & $\mathrm{R}$ \\
\hline Ampicillin & $S$ & $\mathrm{R}$ \\
\hline Rifampicin & $S$ & $\mathrm{R}$ \\
\hline $\begin{array}{l}\text { Sulfamethoxazole/ } \\
\text { trimethoprim }\end{array}$ & $S$ & $\mathrm{R}$ \\
\hline $\begin{array}{l}\text { DNA G }+C \text { content } \\
(\mathrm{mol} \%)\end{array}$ & 69.6 & $68.7-70.1(57.4)^{\star}$ \\
\hline
\end{tabular}

${ }^{\star}$ Results in parentheses obtained from Song et al. (2009). $\dagger$ Negative in API ZYM kit, but positive in API 20NE kit. $\ddagger$, Sensitive; R, resistant.

\section{Emended description of the genus Inhella Song et al. 2009}

The formal description given by Song et al. (2009) remains correct with the exception of the following: some species are non-motile or motile by means of a single polar flagellum; catalase activity is variable; obligately aerobic or facultatively anaerobic; and the DNA G $+\mathrm{C}$ content is 68.7-70.1 mol\%. The predominant polar lipids are PE, PG, PS, DPG and several uncharacterized PLs.

\section{Description of Inhella fonticola sp. nov.}

Inhella fonticola (fon.ti'co.la. L. masc. n. fons fontis a spring, fountain; L. suff. -cola from L. masc. or fem. n. incola an inhabitant of a place, a resident; N.L. n. fonticola an inhabitant of a fountain or spring).

Cells are Gram-negative, obligately aerobic, non-motile, non-spore-forming, rod-shaped and chemo-heterotrophic. PHB accumulation is observed. Bacteriochlorophyll $a$ is absent. After $24 \mathrm{~h}$ of incubation on R2A agar at $25^{\circ} \mathrm{C}$, the mean cell size is approximately $0.3-0.5 \mu \mathrm{m}$ in diameter and $1.0-1.2 \mu \mathrm{m}$ in length. Colonies are yellow, convex, round and smooth with entire edges. The colony size is approximately $0.9-1.1 \mathrm{~mm}$ in diameter on R2A agar after $48 \mathrm{~h}$ of incubation at $25^{\circ} \mathrm{C}$. Growth occurs at $15-40{ }^{\circ} \mathrm{C}$ (optimum, $25^{\circ} \mathrm{C}$ ), at $\mathrm{pH}$ 6.0-10.0 (optimum, $\mathrm{pH} 7.0$ ) and with $0-0.5 \% \mathrm{NaCl}$ (optimum, $0 \%$ ). Positive for oxidase, catalase and DNase activities, and hydrolysis of starch, lecithin, and Tweens 40 and 80 . Negative for urease activity and hydrolysis of casein, corn oil, and Tweens 20 and 60. In API 20NE tests (bioMérieux), positive for assimilation of caprate and negative for nitrate reduction, indole production, glucose acidification, aesculin and gelatin hydrolysis, arginine dihydrolase, urease and $\beta$-galactosidase activities, and assimilation of glucose, arabinose, mannose, mannitol, $\mathrm{N}$-acetylglucosamine, maltose, gluconate, adipate, malate, citrate and phenylacetate. In the API ZYM kit (bioMérieux) alkaline phosphatase, leucine arylamidase and naphthol-ASBI-phosphohydrolase activities are present and C4 esterase, C8 esterase lipase, C14 lipase, valine arylamidase, cystine arylamidase, trypsin, $\alpha$-chymotrypsin, acid phosphatase, $\alpha$-galactosidase, $\beta$-galactosidase, $\beta$-glucuronidase, $\alpha$-glucosidase, $\beta$-glucosidase, $N$-acetyl- $\beta$-glucosaminidase, $\alpha$-mannosidase and $\alpha$-fucosidase activities are absent. The following compounds are utilized as sole carbon sources in the GN2 MicroPlate (Biolog): $\alpha$-cyclodextrin, dextrin, glycogen, Tweens 40 and 80, adonitol, sucrose, $\beta$-hydroxybutyric acid, sebacic acid, L-asparagine, L-histidine, L-ornithine, uridine and 2-aminoethanol. None of the other substrates in the GN2 MicroPlate are utilized. Sensitive to penicillin G, ampicillin, chloramphenicol, gentamicin, rifampicin, kanamycin, tetracycline, novobiocin, streptomycin, sulfamethoxazole plus trimethoprim, nalidixic acid, vancomycin and erythromycin. The major fatty acids $(>10 \%)$ are summed feature 3 (comprising $\mathrm{C}_{16: 1} \omega 7 c$ and/or $\mathrm{C}_{16: 1} \omega 6 c$ ) and $\mathrm{C}_{16: 0}$. The respiratory quinones are Q-8 and Q-6. Exhibits a 
complex polar lipid profile consisting of PE, PG, PS, DPG and four uncharacterized PLs.

The type strain is $\mathrm{TNR}-25^{\mathrm{T}} \quad\left(=\mathrm{BCRC} \quad 80211^{\mathrm{T}}=\mathrm{LMG}\right.$ $25721^{\mathrm{T}}$ ), isolated from a freshwater spring, Maolin Township, Kaoshiung County, Taiwan. The DNA G+C content of the type strain is $69.6 \mathrm{~mol} \%$.

\section{References}

Anzai, Y., Kudo, Y. \& Oyaizu, H. (1997). The phylogeny of the genera Chryseomonas, Flavimonas, and Pseudomonas supports synonymy of these three genera. Int J Syst Bacteriol 47, 249-251.

Biebl, H., Allgaier, M., Tindall, B. J., Koblizek, M., Lünsdorf, H., Pukall, R. \& Wagner-Döbler, I. (2005). Dinoroseobacter shibae gen. nov., sp. nov., a new aerobic phototrophic bacterium isolated from dinoflagellates. Int $J$ Syst Evol Microbiol 55, 1089-1096.

Breznak, J. A. \& Costilow, R. N. (1994). Physicochemical factors in growth. In Methods for General and Molecular Bacteriology, pp. 137154. Edited by P. Gerhardt, R. G. E. Murray, W. A. Wood \& N. R. Krieg. Washington, DC: American Society for Microbiology.

Chen, W. M., Laevens, S., Lee, T. M., Coenye, T., De Vos, P., Mergeay, M. \& Vandamme, P. (2001). Ralstonia taiwanensis sp. nov., isolated from root nodules of Mimosa species and sputum of a cystic fibrosis patient. Int J Syst Evol Microbiol 51, 1729-1735.

Chun, J., Lee, J.-H., Jung, Y., Kim, M., Kim, S., Kim, B. K. \& Lim, Y. W. (2007). EzTaxon: a web-based tool for the identification of prokaryotes based on $16 \mathrm{~S}$ ribosomal RNA gene sequences. Int J Syst Evol Microbiol 57, 2259-2261.

Collins, M. D. (1985). Isoprenoid quinone analysis in classification and identification. In Chemical Methods in Bacterial Systematics, pp. 267-287. Edited by M. Goodfellow \& D. E. Minnikin. London: Academic Press.

Embley, T. M. \& Wait, R. (1994). Structural lipids of eubacteria. In Chemical Methods in Prokaryotic Systematics, pp. 121-161. Edited by M. Goodfellow \& A. G. O’Donnell. Chichester: Wiley.

Ezaki, T., Hashimoto, Y. \& Yabuuchi, E. (1989). Fluorometric deoxyribonucleic acid-deoxyribonucleic acid hybridization in microdilution wells as an alternative to membrane filter hybridization in which radioisotopes are used to determine genetic relatedness among bacterial strains. Int J Syst Bacteriol 39, 224-229.

Felsenstein, J. (1981). Evolutionary trees from DNA sequences: a maximum likelihood approach. J Mol Evol 17, 368-376.

Felsenstein, J. (1993). PHYLIP (phylogeny inference package), version 3.5c. Distributed by the author. Department of Genome Sciences, University of Washington, Seattle, USA.

Garrity, G. M., Bell, J. A. \& Lilburn, T. (2005). Order I. Burkholderiales ord. nov. In Bergey's Manual of Systematic Bacteriology, 2nd edn, vol. 2C, pp. 575-763. Edited by D. J. Brenner, N. R. Krieg, J. T. Staley \& G. M. Garrity. New York: Springer.

Gomila, M., Bowien, B., Falsen, E., Moore, E. R. \& Lalucat, J. (2008). Description of Roseateles aquatilis sp. nov. and Roseateles terrae sp. nov., in the class Betaproteobacteria, and emended description of the genus Roseateles. Int J Syst Evol Microbiol 58, 6-11.

Hall, T. A. (1999). BioEdit: a user-friendly biological sequence alignment editor and analysis program for Windows 95/98/NT. Nucleic Acids Symp Ser 41, 95-98.

Kalmbach, S., Manz, W., Wecke, J. \& Szewzyk, U. (1999). Aquabacterium gen. nov., with description of Aquabacterium citratiphilum sp. nov., Aquabacterium parvum sp. nov. and Aquabacterium commune sp. nov., three in situ dominant bacterial species from the Berlin drinking water system. Int J Syst Bacteriol 49, 769-777.

Kimura, M. (1983). The Neutral Theory of Molecular Evolution. Cambridge: Cambridge University Press.

Kluge, A. G. \& Farris, F. S. (1969). Quantitative phyletics and the evolution of anurans. Syst Zool 18, 1-32.

Kumar, S., Tamura, K. \& Nei, M. (2004). MEGA3: integrated software for molecular evolutionary genetics analysis and sequence alignment. Brief Bioinform 5, 150-163.

Maidak, B. L., Cole, J. R., Lilburn, T. G., Parker, C. T., Jr, Saxman, P. R., Farris, R. J., Garrity, G. M., Olsen, G. J., Schmidt, T. M. \& Tiedje, J. M. (2001). The RDP-II (Ribosomal Database Project). Nucleic Acids Res 29, 173-174.

Malmqvist, A., Welander, T., Moore, E., Ternstrom, A., Molin, G. \& Stenstrom, I. (1994). Ideonella dechloratans, gen. nov., sp. nov., a new bacterium capable of growing anaerobically with chlorate as an electron acceptor. Syst Appl Microbiol 17, 58-64.

Mesbah, M., Premachandran, U. \& Whitman, W. B. (1989). Precise measurement of the $\mathrm{G}+\mathrm{C}$ content of deoxyribonucleic acid by highperformance liquid chromatography. Int J Syst Bacteriol 39, 159-167.

Murray, R. G. E., Doetsch, R. N. \& Robinow, C. F. (1994). Determinative and cytological light microscopy. In Methods for General and Molecular Bacteriology, pp. 21-41. Edited by P. Gerhardt, R. G. E. Murray, W. A. Wood \& N. R. Krieg. Washington, DC: American Society for Microbiology.

Nokhal, T.-H. \& Schlegel, H. G. (1983). Taxonomic study of Paracoccus denitrificans. Int J Syst Bacteriol 33, 26-37.

Powers, E. M. (1995). Efficacy of the Ryu nonstaining KOH technique for rapidly determining gram reactions of food-borne and waterborne bacteria and yeasts. Appl Environ Microbiol 61, 3756-3758.

Ramana, Ch. V., Sasikala, Ch., Arunasri, K., Anil Kumar, P., Srinivas, T. N., Shivaji, S., Gupta, P., Süling, J. \& Imhoff, J. F. (2006). Rubrivivax benzoatilyticus sp. nov., an aromatic, hydrocarbon-degrading purple betaproteobacterium. Int J Syst Evol Microbiol 56, 2157-2164.

Rapala, J., Berg, K. A., Lyra, C., Niemi, R. M., Manz, W., Suomalainen, S., Paulin, L. \& Lahti, K. (2005). Paucibacter toxinivorans gen. nov., sp. nov., a bacterium that degrades cyclic cyanobacterial hepatotoxins microcystins and nodularin. Int J Syst Evol Microbiol 55, 1563-1568.

Saitou, N. \& Nei, M. (1987). The neighbor-joining method: a new method for reconstructing phylogenetic trees. Mol Biol Evol 4, 406425.

Sasser, M. (1990). Identification of bacteria by gas chromatography of cellular fatty acids. Newark, DE: MIDI Inc.

Smibert, R. M. \& Krieg, N. R. (1994). Phenotypic characterization. In Methods for General and Molecular Bacteriology, pp. 607-654. Edited by P. Gerhardt, R. G. E. Murray, W. A. Wood \& N. R. Krieg. Washington, DC: American Society for Microbiology.

Song, J., Oh, H.-M., Lee, J.-S., Woo, S.-B. \& Cho, J.-C. (2009). Inhella inkyongensis gen. nov., sp. nov., a new freshwater bacterium in the order Burkholderiales. J Microbiol Biotechnol 19, 5-10.

Spring, S. (2002). The genera Leptothrix and Sphaerotilus. In The Prokaryotes: An Evolving Electronic Resource for the Microbiological Community, 3rd edn, p. 39. Edited by M. Dworkin, K. H. Schleifer \& E. Stackebrandt. New York: Springer-Verlag.

Spring, S., Kampfer, P., Ludwig, W. \& Schleifer, K. H. (1996). Polyphasic characterization of the genus Leptothrix: new descriptions of Leptothrix mobilis sp. nov. and Leptothrix discophora sp. nov. nom. rev. and emended description of Leptothrix cholodnii emend. Syst Appl Microbiol 19, 634-643.

Suyama, T., Shigematsu, T., Takaichi, S., Nodasaka, Y., Fujikawa, S., Hosoya, H., Tokiwa, Y., Kanagawa, T. \& Hanada, S. (1999). Roseateles 
depolymerans gen. nov., sp. nov., a new bacteriochlorophyll acontaining obligate aerobe belonging to the beta-subclass of the Proteobacteria. Int J Syst Bacteriol 49, 449-457.

Thompson, J. D., Gibson, T. J., Plewniak, F., Jeanmougin, F. \& Higgins, D. G. (1997). The CLUSTAL_X windows interface: flexible strategies for multiple sequence alignment aided by quality analysis tools. Nucleic Acids Res 25, 4876-4882.

Wayne, L. G., Brenner, D. J., Colwell, R. R., Grimont, P. A. D., Kandler, O., Krichevsky, M. I., Moore, L. H., Moore, W. E. C., Murray, R. G. E. \& other authors (1987). International Committee on Systematic Bacteriology. Report of the ad hoc committee on reconciliation of approaches to bacterial systematics. Int J Syst Bacteriol 37, 463-464.
Weisburg, W. G., Barns, S. M., Pelletier, D. A. \& Lane, D. J. (1991). $16 \mathrm{~S}$ ribosomal DNA amplification for phylogenetic study. J Bacteriol 173, 697-703.

Willems, A. \& Gillis, M. (2005). Family IV. Comamonadaceae Willems, De Ley, Gillis and Kersters 1991a, 447 ${ }^{\mathrm{VP}}$. In Bergey's Manual of Systematic Bacteriology, 2nd edn, vol. 2C, pp. 686-763. Edited by D. J. Brenner, N. R. Krieg, J. T. Staley \& G. M. Garrity. New York: Springer.

Willems, A., Gillis, M. \& De Ley, J. (1991). Transfer of Rhodocyclus gelatinosus to Rubrivivax gelatinosus gen. nov., comb. nov., and phylogenetic relationships with Leptothrix, Sphaerotilus natans, Pseudomonas saccharophila, and Alcaligenes latus. Int J Syst Bacteriol 41, 65-73. 